\title{
Re-creating rural performing arts for tourism in Indonesia
}

\section{Santosa Soewarlan}

To cite this article: Santosa Soewarlan (2018): Re-creating rural performing arts for tourism in Indonesia, Journal of Tourism and Cultural Change, DOI: 10.1080/14766825.2018.1541993

To link to this article: https://doi.org/10.1080/14766825.2018.1541993

曲 Published online: 07 Nov 2018.

Submit your article to this journal ¿ᄌ

Џll Article views: 8

View Crossmark data ¿ 


\title{
Re-creating rural performing arts for tourism in Indonesia
}

\author{
Santosa Soewarlan \\ Department of Ethnomusicology, Indonesia Institute of the Arts (ISI), Surakarta, Indonesia
}

\begin{abstract}
This article explores the creative process driven by an understanding of local values and how villagers wished to present their life, land and culture to the tourists visiting the area. The local community brought their knowledge of both the artforms and the significance they held in terms of village identity and cohesion, whilst the research team helped to integrate the chosen elements into a coherent large-scale performance. The practical steps involved the philosophical underpinnings in terms of authenticity. A typical member of the public's idea of authenticity may be of something that is traditional, that has remained unchanged for countless generations. In practice, the arts do not operate in this way, both artforms and the meanings they hold for people are in a constant state of flux, changing to meet the changing needs and aspirations of society. Therefore, in creating a performance that could present an 'authentic' view of village life for tourists, we began by understanding the values of the community, and allowed the performance to develop organically from this, based on a local legend that expressed both the history of the area and the values of the villagers.
\end{abstract}

\section{ARTICLE HISTORY}

Received 26 August 2017

Accepted 22 October 2018

\section{KEYWORDS}

Tourism; authenticity; performing arts; identity; meaning; environments

\section{Introduction}

Over the last four decades, the growth in global tourism has been of great importance in the economic, social, and cultural development of less wealthy countries (Rogerson \& Rogerson, 2014, p. S190). Alongside the development of related infrastructure such as international and internal transport networks, hotels and other commercial enterprises, the promotion of countries as a unique tourist destination has resulted in what Yamashita describes as 'a field of cultural production on a global scale' (1999, p. 177).

Indonesia, despite its great natural beauty, its rich and varied cultural manifestations, and a competitive currency, has not yet succeed in attracting a commensurate level of international tourism. Although the number of tourist visiting Indonesia increased by $5.7 \%$ in 2015, a little higher than that in neighbouring Malaysia (3.7\%), according to 'Tourism Industry Indonesia' (http://www.indonesia-investments.com/business/industriessectors/tourism/item6051?) only 10 million tourists visited Indonesia in 2015, considerably lower than in Singapore (15 million) and Malaysia (27 million). Most of the visitors choose Bali, the most popular and attractive tourist object, as the main destination for their 
travels. In order to attract tourists, new concepts and strategies need to be formulated (Tan \& Yang, 2014, p. 4370).

Mbaiwa observes that 'if tourism is to become sustainable, it should adhere to economic, social, environmental and ethic considerations in host regions' (2004, p. 164). A good tourism programme will provide ways for visitors to experience the local arts and culture in the contexts they arose from, which is appealing to travellers as an expression of local identity (Human, 2010, p. 131).

This paper describes the development of a programme to attract domestic and foreign tourists to Parangijo, aforested [a forested] mountain region of the Karanganyar Regency (Central Java, Indonesia). Rather than analysing the numbers, itineraries, accommodation and spending patterns of tourists, this study focuses on how to empower local artists and ordinary villagers to stage events in the area, specifically the collaborative performance at one of the area's prime natural attractions: the Parangijo waterfall.

The collaboration involved a team of village artists and academics from Institut Seni Indonesia (Institute of Performing Arts) Surakarta: musician, ethnomusicologist and author of this paper, Santosa Soewarlan, Arif Jati Purnomo (lead creator), Joko Budiwiyanto (designer), Sri Harto (musician), and Sri Setyoasih (dancer). The team worked with villagers in Parangijo to explore elements of local performing arts and evolve a new performance: one with its roots in the village's traditions, but evolved to fit the new context of sustainable tourism.

\section{Methodology}

The research team focused on how to adapt local artistic forms to create a performance that was both suitable for a tourism programme and had integrity in terms of representing the local area in the way the villagers wanted. This involved a number of steps: one-to-one interviews aimed at identifying local artforms and understanding the values they represented to people, group discussions to determine which elements to draw upon to create the dance drama, creation of the actual performance (plot, composition, choreography, costumes), conducting workshops and rehearsals with the local villagers, and exploring natural outdoor venues within which the drama could be set.

The aim of the programme was to avoid the conventional approach to rural tourism in which the main object is to passively observe rural scenery and lifestyles (Zie, 2015, p. 14), and instead give visitors to the region the opportunity to experience the local arts in the geographical, religious and historic context they arose from (Zhang, 2013, p. 5).

Including performing arts in tourism programmes helps fulfil some of the underlying strategies goals of tourism. Not only does it provide new sources of income: if such projects are conducted sensitively, they can empower local people to maintain and hand down local arts by imbuing them with new meanings and functions relevant to the contemporary world. This process of recontextualization through a community-driven project can also provide the opportunity for people to reflect upon the relationship between their local culture and the setting it grew out of, providing insight into the unity and interdependence of these elements, and how they combine to make local artforms unique.

The essence of a performance gains lies in the combination of its various elements: dance, music, song, costumes and scenery. Each of these elements carries individual meaning, and they are brought together within a collaborative artistic framework that 
can seek out the synergy between them, forming a coherent whole from which spectators can make sense of the performance. In our project, the extra collaborator was nature: waterfall, river, cliffs, valley and pine forest were important contributors to the aesthetic meaning of the performance. Local artists who have good understanding of village customs manifest their creations in natural contexts, using 'symbolic landscape' (della Dora, Lorimer, \& Daniels, 2011, p. 265), a symbol that represents surroundings by manipulating the environment to provide a geographical framework for their art.

By synchronizing these elements in our performance, we hoped to represent the identity of the village in a meaningful way that could be shared with visitors seeking a taste of rural life and culture.

\section{About the area}

The setting of our project was the Parangijo waterfall on the western cliff of Mount Lawu (peak 3265 meters), Ngargoyoso sub-district, on the border of East and Central Java, Indonesia. The setting has three strong characteristics: beautiful natural scenery, a fascinating religious background, and a unique historical heritage. The route from Karangpandan (the neighbouring sub-regency to the west) to Parangijo is lined with cultivated terraces and visitors can observe traditional mountain farming practices as they travel to the site. The year-round mild, fresh mountain air $\left(22-31^{\circ} \mathrm{C}\right)$ makes it a comfortable place for travellers to stay, and the stunning scenery - both natural and cultivated - make the area excellent place for sightseeing and exploring.

Like other areas in Karanganyar Regency, Ngargoyoso's religious makeup is rather different from mainstream Javanese culture. Islam was introduced to Java in the sixteenth century, replacing Hindu-Buddhism (which itself reached Java from India around the ninth century) as the main religion. Although Islam is now the official religion of Indonesia, for centuries many Javanese have maintained older customs, some dating back to animist beliefs from before the Hindu-Buddhist period. These local beliefs, referred to by Clifford Geertz as abangan (1960, p. 5), are kept alive through regular practices such as weekly offerings to supernatural powers, monthly ceremonies for the safety and prosperity, and rituals for personal purposes. Furthermore, the area is home to some of the last practitioners of Hinduism in Java, and is the location of the ruins of a pair of Hindu temples, the male Candi Cetho and female Candi Sukuh. Both Hindu and older Javanese religious practices and rituals thus form part of the cycle of everyday village life here, alongside various Islamic practices, marking it out as distinct from both mainstream Javanese culture and the majority Hindu culture of Bali (Figure 1).

In addition to being the centre of local Hindu activities, Sukuh and Cetho temples represent the tangible heritage of Hindu culture in the area and the history of religion in Indonesia. Rediscovered in 1815 by the colonial Resident of Surakarta, Major J. M. Johnson, ${ }^{1}$ they date back to the fifteenth century, when Hindus were forced to flee East Java following its conquest by devotees of Islam. The temples both have three terraces representing the levels of life in Hindu philosophy. Local and Balinese Hindus believe they share common ancestors, and often hold rituals and ceremonies together at the temples.

The natural scenery, religious beliefs and local history thus all play a part in shaping the identity of the local area. They affect the way people conduct their lives, they imbue their worldview, and they are integral parts of the arts and cultural makeup of the area. 


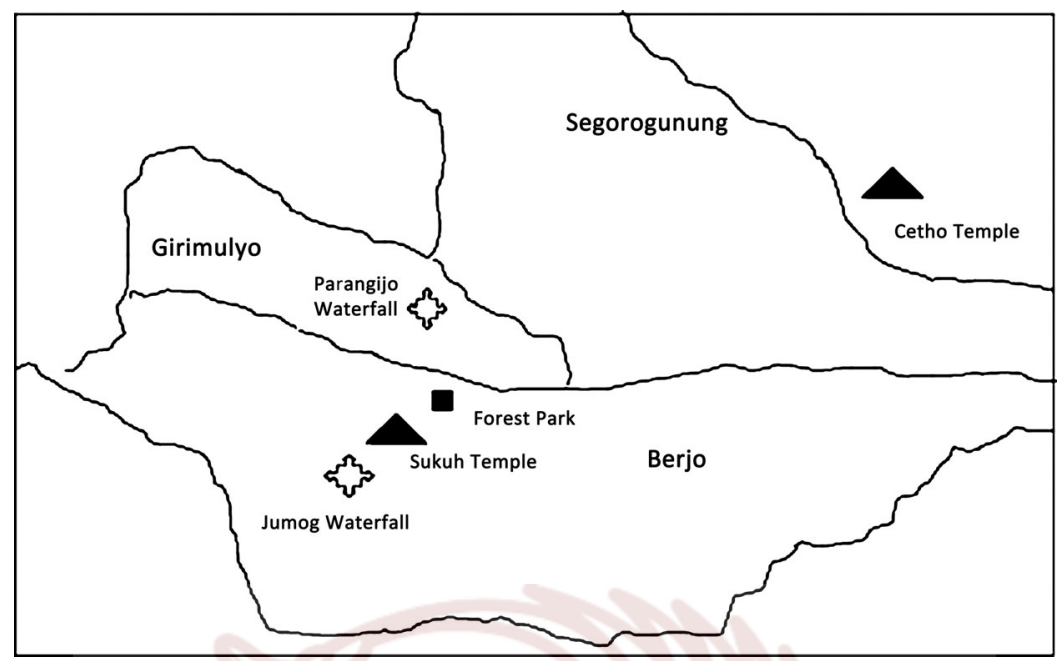

Figure 1. Map of Ngargoyoso showing Parangijo waterfall and the surrounding area.

\section{Arts and traditions in Ngargoyoso}

Arts in Ngargoyoso figure in a variety of socio-cultural contexts. Most of them are associated with community rituals and ceremonies, where they are used to metaphorically represent the relationship between humans and supernatural beings, human-to-human interactions, and to cast imaginations of future life. At such events, spiritual leaders and neighbours are invited to observe the ceremony and to come together to pray for peace and prosperity.

In ritual celebrations, people use terbangan, a devotional music associated with Islamic culture. Using single-headed Arabic drums, musicians sing songs to praise God and to call for peace, safety and prosperity. Due to the need to adjust to local tastes, musicians frequently integrate Islamic elements with local ones, combining Javanese and Arabic languages, mixing old melodies with new, and creating new musical structures, resulting in a unique local form of Islamic music. These have resulted the variety of Islamic arts: hadrah, rebana, selawatan, and other forms of music.

Kentongan bamboo percussion music was once one of the major musical forms in mountain villages. In the past, kentongan groups were widely distributed in these areas and used 'as a means of collective communication in general, and warning in particular' (Barker, 1999, p. 114) especially in the days before telephone and other remote communication devices. Kentongan instruments were used to alert people to urgent or unexpected dangers: floods, suicide, theft or fire could be effectively communicated to people in neighbouring areas. More recently, they have been used by night patrolmen as they walk together through the streets to protect their homes from the possible dangers and disasters.

One popular folk dance is reyog, which has been adopted from East Java. This dramatic dance uses sophisticated choreography, requiring great strength and acrobatic ability, and requires a high degree of training. It's most iconic aspect is the lion dance, where two male dancers stage a fight or demonstrate their strength whilst gripping giant lion masks 
decorated with peacock feathers around the mask. As well as imitating animals, dancers evoke natural forces, and various mythical characters such as demons and monsters.

One of the most important rituals in terms of our project was the one celebrating a local female hero Nyai Gadhung Mlathi, the founder of the village, who protects the security and prosperity of the village. This ritual evokes deep meanings connected to objects which exist in the village: its irrigation system, sacred places and tiger head monuments, and certain mythical figures connected with the villager are evoked. This ritual reasserts the connection between the spiritual domain and the every day life of the village, and can be seen as an expression of inhabitants' collective worldview, as well as the individual character and history of the village.

Folktales, such as the one on which this ritual is based, represent a powerful means to preserve local knowledge and values. Many ideas, beliefs and worldviews are kept alive in the images of daily life that such tales present, while their dramatic narrative elements provide the ideal foundation for a dance drama. For these reasons, this story, and elements of the ritual around it, were chosen as the main sources of inspiration for the performance we developed.

\section{The concept of performance}

Art not only plays a role in keeping tradition alive, but also in sustaining human activities. Marian McDonald et al. write that art precursors actions through the formation of ideas, forming 'the quality of the light with which we predicate our hopes and dreams toward survival and change, first made into language, then into idea, then into more tangible action' (McDonald, Antunez, \& Gottemoeller, 2006, p. 266). In this sense, the transformation of art into idea occurs at a cognitive level and then becomes reality in daily actions. It is in this process that local concepts, tastes, and beliefs are reflected to construct worldviews in a specific context. This worldview is then reactivated to represent locality and village values. This process is significant because artistic performances strengthen the foundations of daily activities, weekly rituals, monthly or yearly ceremonies. Especially, in ceremonies and village festivals, the treatment and content of the arts reflect the conceptualization by village artists who wish to express the significance of certain aspects of the social and cultural life of the community.

In creating a performance for tourists, artists can still draw upon what Davies (2004, p. 163) calls 'intentionally characterized mental states' such as beliefs, desires, hopes and fears. Thus, to forge a new approach suited to the different performance context, the basic concepts contained in legends, nature, cosmology and so on remain a rich source to draw from. This approach can be used to develop new roles for the arts that make them valuable and relevant to the present-day community, without compromising their relevance in conventional contexts: festivals, weddings, circumcisions and religious rites.

This can be seen as a kind of 'new authenticity' where traditional arts are not treated as a reified, fixed discipline from some imagined pre-industrial past, but something that is meaningful to both artists and audiences in this day and age. It is authentic from an artistic point of view, because it represents an evolving approach which changes with the new realities of peoples' lives - as music, dance and stories have always done. And it is authentic from the audience's point of view, because it draws on living traditions that provide the chance to experience them in the environment from which they emerged, 
something which can in practice be difficult for outsiders to access unless they happen to visit at the time of a scheduled ceremony or festival.

The shift in focus to a performance for tourists involves a shift in perspective for rural artists accustomed to performing in conventional contexts: from a ritualistic, ceremonial, religious setting to a secular one. The team aimed to facilitate this shift of focus at every stage of the creative process: developing initial concepts, finding an appropriate theme, choosing the medium of expression, determining the structure of the performance, creating costumes, choreographing the dance and composing the music. Our performance was to be a true community event, involving many villagers with no previous experience in the arts, thus there was a significant element of teaching involved: how to produce costumes, how to dance, and how to play music.

It is hoped that this activity will, in the long term, help provide the experience needed for local villagers to work together as a team to develop more arts programmes for tourists.

\section{Exploring location and local arts}

The first question to address was what kind of venue was appropriate. Albert and Hazen write that the ideal venue should 'be authentic, integrated and 'of outstanding universal value' (2010, p. 56), while Smith-Autard speaks of the unique character of a space that radiates 'inner energy' which can be harnessed to reveal identity $(2009, \mathrm{p}$. 3). The venue, in other words, should not exist in a vacuum without meaning: rather it possesses vitality to represent a 'distinctiveness of personality'. We felt that Parangijo waterfall and its surroundings met these criteria because it represents the natural environment and is already a favourite tourist spot (Figure 2).

Having chosen a performance space intimately linked to the life cycles and values of the community, the next step was to explore aspects of the local arts that would reflect this approach and express the cultural identity of the village in a way that would be accessible to outsiders.

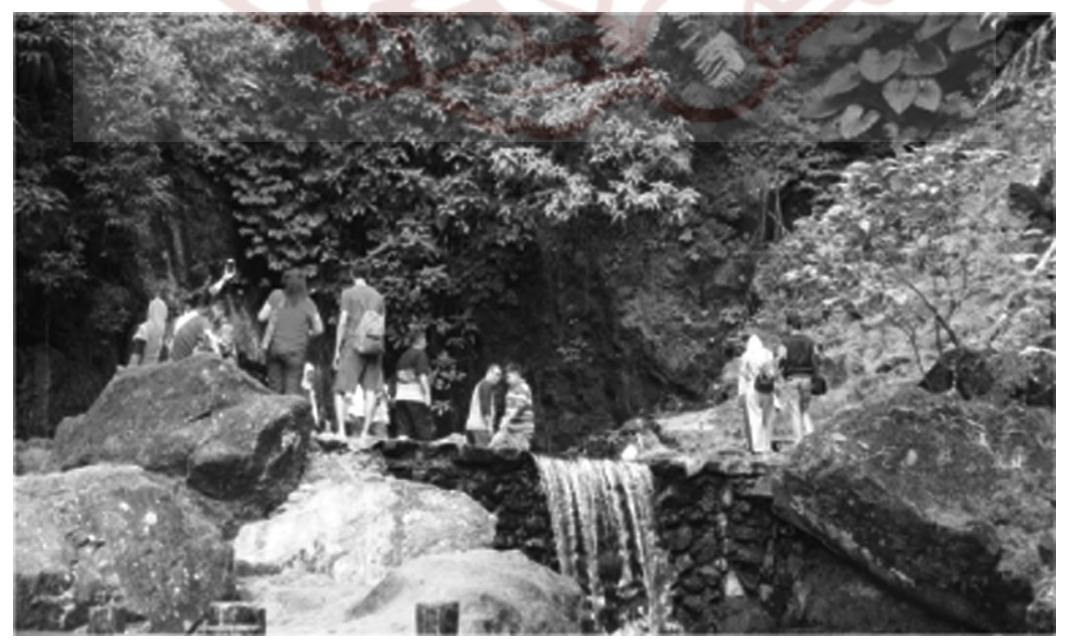

Figure 2. The Parangijo waterfall and surrounding environment (Photo: Santosa). 
To begin this process, the team conducted interviews with people who knew about local arts, values and traditions. Several traditional art forms were proposed as a result of these discussions. Some participants proposed using reyog, arguing that the inner power which forms a deep part of the reyog philosophy would interest tourists. Other groups suggested using lesung (mortar) music, feeling that as music that supported the team job of rice pounding it represented cooperative values among village people. However, in group discussions it was felt that these traditions were similar to those found in many other villages across the region and would not bring the strong sense of local identity we wanted to achieve, and that tourists would not be interested in travelling to such a remote place to see the same kind of art they could experience in other places.

In an interview Pak Suripto, a local expert, mentioned the legend of Macan Gadhungan, 'The False Tiger', a story that had existed in the area for generations, told as a bedtime story, and also integrated into local rituals and history. Narratives such as this become a part of a community because they have the power to formulate ideas that are meaningful to people's lives (Connell, 2014, p. 83). Macan Gadhungan is no exception, incorporating elements of local culture that people want to keep alive: traditions of ceremonies in sacred places in villages, the use of a tiger's head statue in yearly rituals, the introduction of irrigation systems, and a shared set of beliefs and values.

The idea of basing the performance on Macan Gadhungan was debated in a group discussion. The research team pointed out that the ideals this legend encapsulates - such as social justice, heroism and wisdom - are themes that can be expressed powerfully through the arts, while the details of the narrative are strongly connected with the immediate area. Furthermore, as a story it accommodates both local values and worldviews, and the aspirations of tourists to experience something unique to the places they visit. The villagers agreed that this would be a suitable strategy: the story resonated with local values and history, they would enjoy performing it, and it would give visitors to the area some real insight into their sense of village identity.

\section{Plot and music}

The team and the local artistic leaders started by creating a storyline based on Macan Gadhungan that would form the basis from which other aspects of the performance - the choreography, music and costumes - would be created.

The story tells of an old woman, Nyai Gadhung Mlathi, who lives peacefully with her beautiful daughter Klabang Retno in a small village called Gadhungan. They have a thriving garden, but it is drying out, so one day Nyai Gadhung Mlathi decides to hold competition to water it, offering her daughter's hand in marriage to the one who can bring it back to life. Kyai Sukuh, a powerful old man from a neighbouring village, brings soldiers to dig ditches to water the garden through the existing irrigation system, winning the contest. $\mathrm{He}$ is sure that he will be able to marry the beautiful Klabang Retno, but Nyai Gadhung Mlathi breaks her promise and does not allow the marriage because he is too old. In his anger, he curses the woman, her daughter and all people in the village, turning them into tigers and centipedes. Led by Nyai Gadhung Mlathi, the tigers and centipedes form troops to fight Kyai Sukuh's soldiers, but are defeated and flee to the deep forest surrounding the village. Realizing that Klabang Retno also refuses to marry Kyai Sukuh, Nyai Gadhung Mlathi and her followers decide to stay in the forest, taking on the role of protectors of 
the village, who appear to assist villagers when they hold ceremonies for safety and prosperity.

The story contains many powerful narrative themes: collaborative action, a battle over evil conduct, and the search for justice. The antecedences and consequences of events in the story are integrated with the ideals it is built on. The setting and the flow of the story follow the structure of Freytag's pyramid (Freytag, 1876, p. 100) in which the constituent parts correlate with one another in a dynamic sequence of exposition, rising action, climax, falling action, and resolution (Figure 3), creating a coherent unity.

Following the dynamic of the narrative in Figure 3, the performance we created opens with the calm, serene, peaceful life of Nyai Gadhung Mlathi's family lives, the tranquil atmosphere depicted through simple movements and sounds. Accompanying the crowds of dancers (totalling 25 men and women), the bamboo ensemble plays soft, quiet sounds representing the unity, tranquillity of the village.

Their tranquillity is troubled by Klabang Retno's anxiety and sorrow as her beautiful garden dries out. With a little tension in rhythm, the music mirrors Klabang Retno's movements and facial expressions showing her fear of loosing the gorgeous garden.

The dramatic tension increases in the next scene when Kyai Sukuh and his followers start irrigating the garden, and Kyai Sukuh becomes angry when he is denied Klabang Retno's hand in marriage. The irrigation process is accompanied by a lively chorus, increasing in dynamic to reflect the strong motivation and hard work of Kyai Sukuh's soldiers as they dig away. Kyai Sukuh's incredible anger when Nyai Gadhung Mlathi refuses to allow the marriage is marked by a sudden dynamic change, as the singers shout out his curse.

The dramatic climax comes with the battle between Kyai Sukuh's soldiers and the villagers whom he has transformed into tigers and centipedes. This scene attempts to capture the chaos and noise of battle, involving all the dancers, supported by raucous music.

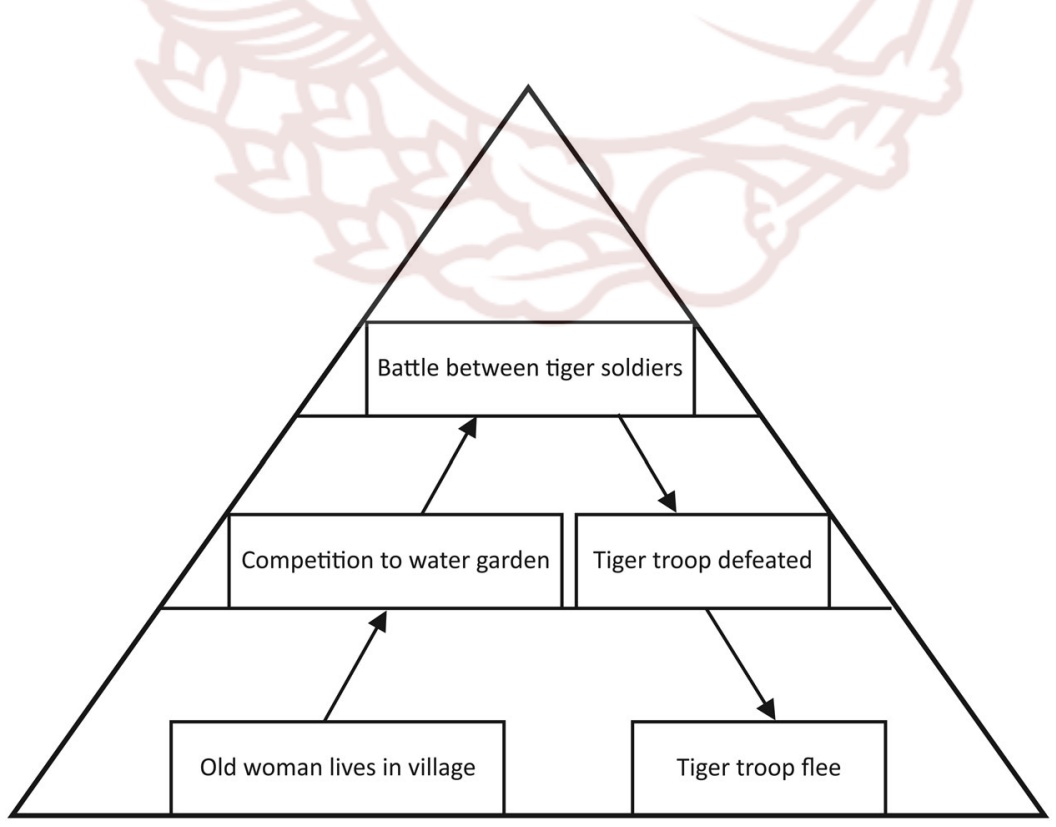

Figure 3. The dynamic of Macan Gadhungan according to Freytag's pyramid system. 
Eventually, Kyai Sukuh's soldiers win the battle. The tigers and centipedes flee and, as the soldiers depart, the music calms once again to represent the tranquil atmosphere among Nyai Gadhung Mlathi and her followers, who have taken on their new role as protectors of the village.

\section{Rehearsals and workshops}

As this was a community project, we aimed to be as inclusive as possible to keep all elements of the music, choreography and craftwork simple so that everyone could get involved, regardless of experience. The focus, especially with the dance and musical elements, was to develop material that would interest people with little or no previous performance experience to internalize, freeing them up to focus not on the complexities of their own part, but on their interactions with fellow performers and on the function of their role within the performance as a whole. Four groups were established: dancers, musicians and singers, costume makers, and souvenir crafters.

One hundred local elementary, secondary, and high-school students were involved as dancers. They learned basic movements of tigers and centipedes - jumping, crawling, running, rolling over the stage - as well as imitating traditional movements of Bujangganong, the demon character in the aforementioned reyog dance. Their teachers helped select participants from the student population and were also involved in managing their training. They were divided various groups: protagonists (Nyai Gadhung Mlathi) and antagonists (an authoritative man from neighbouring village Kyai Sukuh) whose interactions and unequal power relationships drive the story, the troops of tigers (female, male, young, old) and centipedes, representing unity in the face of oppression, and the outside soldiers brought by Kyai Sukuh.

The musicians and singers were adults: farmers, office workers, and food vendors. As they were not trained artists, we needed music that would be familiar to them, whilst reflecting the local culture and environment. We therefore based the composition on kenthongan (patrol music) described above. Although, like reyog and lesung, this music is not specific to this area - indeed it was once heard across Java and in parts of Malaysia as well - it attracted people to enjoy playing the music. In creating music to represent the content of the legend, we avoided applying new methods of playing the instruments and stuck to traditional treatment.

While the majority of musicians and dancers were not specialists in their area, the constume-makers were in fact already tailors, familiar with making ordinary clothing. This group were tasked with realizing designs suggested by the creative leader and produced some fantastic costumes for the tigers and centipedes. The tigers had black-stripes design printed on white and brown clothes that covered the dancers' body. Centipedes were dressed in dark-brown, bearing claws on their heads.

A mix of school children, food vendors and farm workers joined the souvenier-making group, producing keyrings and tiger masks to sell on the day of the performance. This was an important part of the process, as it helped to integrate all domains of local arts into the performance, and allowed more villagers to get involved in the creative process. The same team also created papier maché tiger masks for the dancers, giving them a direct role in the creative side of the performance. 
Rehearsals commenced three months prior to the performance in January 2010. Although the locals were familiar with the content of the story, they needed time to internalize their role and get used to collaborating in a huge production involving 150 participants. For many of the dancers and musicians, participation in this kind of production was a new experience, requiring development of new skills, such as performing with awareness of both the musical composition and choreography, allowing them to interact creatively with other participants.

As mentioned above, there was an important fifth element of the collaboration: the natural environs of Ngargosoyo. The waterfall, forest, fields and even the chilly mountain air formed the very foundation of the performance, representing the very land from which the legend, craft, dance, music, literature and songs being presented had sprung.

The road to the village climbs into the mountains, traversing valleys lined with terraces and steeply sloping fields, allowing a natural introduction to the setting of the legend. The stage was open-air, in a small, flat $150 \mathrm{~m}^{2}$ field below the waterfall, surrounded by small trees and with a shallow stream running through it. No seats were necessary; instead watchers were left to find their own places to settle around the performance space.

The running waterfall and surrounding forest provided the backdrop, the clear water flowing from the waterfall through the performance space reflecting the connection between the story and its environment. The natural views, green forests and hilly landscape were integrated into the choreography of dance, the calm bamboo music reflected the character of the environment, the colours of the costumes emphasized interaction with those of the surrounding environment, and the chill, clean mountain air heightened the atmosphere of the performance.

The interaction between drama and environment was particularly powerfully expressed in scenes with the tigers, who danced on boulders, played in the river and gathered around trees, encouraging the audience to engage with the natural surroundings not just as a background to the plot, but as an integral part of it (Figure 4).

\section{Discussion: the question of authenticity}

As mentioned above, the search for 'authenticity' is often an important aspect of tourism; for many, travel represents a chance to experience different perspectives on how people can live and interact with each other and the world around them. However, authenticity is a slippery term, meaning different things to different people, and different things depending on the kind of object being discussed. At worst, a misappropriation of the concept of authenticity can lead to objectification of the other and a reification of cultural traces to conform to an imagined, idealized past.

Albert et al. define authenticity in tangible cultural heritage as a 'complete representation of features and processes [that convey] the totality of the value, [that is, the] materially original or genuine product of its time' (2010, p. 60). Such a definition, however, is ill-suited to the performing arts which, unlike architectural heritage, do not have a clearly-definable physical form that lingers through the ages, and are often subject to significant change from generation to generation.

The medium of performance is inherently ephemeral: the work ceases to exist once the performance has been staged. Musical sounds and dance movements do not, of themselves, leave a physical trace, and although technologies of the last hundred-or-so years 


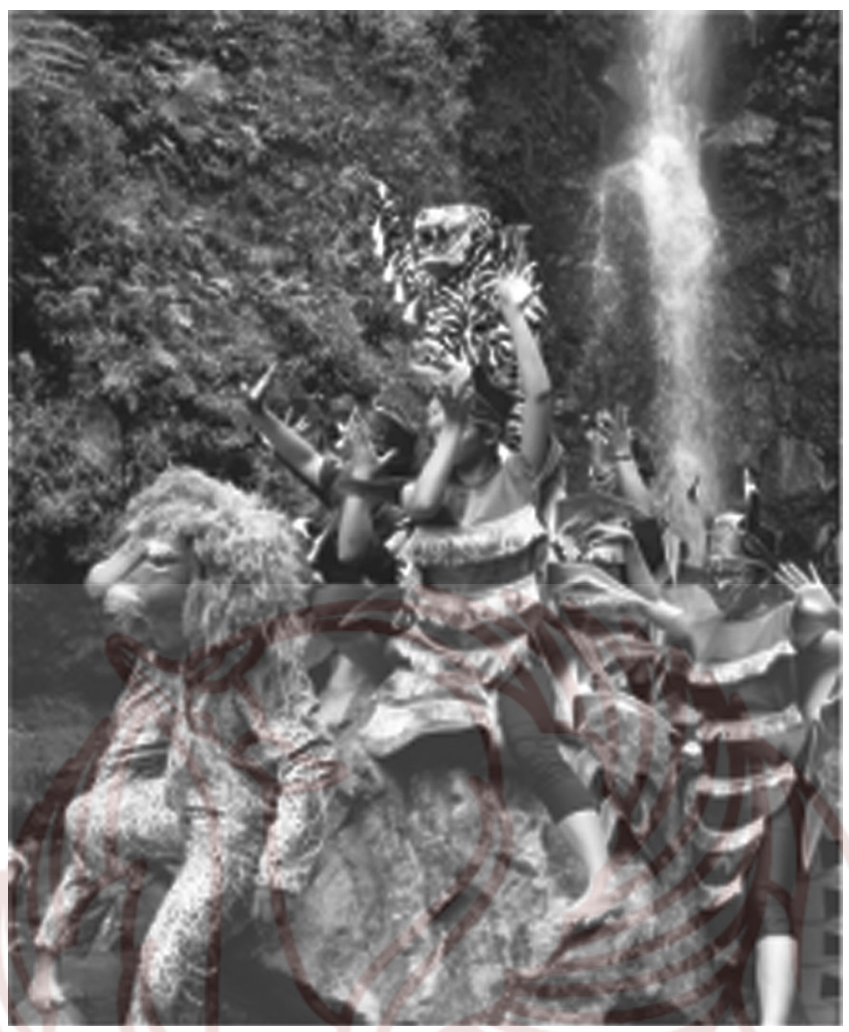

Figure 4. Integrating dance, music, and the natural environment into the performance (Photo: Joko Budiwiyanto).

have allowed us to record sound, still images and video, bereft of the actual performance context, the flow of communication and meanings between artists, audiences, the artistic work and the space it is performed in, these are at best imperfect reproductions.

Rather than preserving the originality of its materials, then, authenticity in the performing arts can be better articulated through negotiation of context. The aim is to preserve artforms 'not in terms of a presupposed original culture, but in terms of everyday practices and their continuous transformations' (Theodossopoulos 2013, pp. 398-400). Huib Schippers emphasizes that authenticity can be achieved through transformation in the context of a 'living tradition' in which changes are necessary (or mandatory), as long as they do not go beyond their conventional boundaries, suggesting these changes are an inherent part of the essence in which tradition keeps the art alive throughout history (2006, p. 335).

Hiroyuki Hashimoto believes that, regardless of the sceptical position from essentialist's perspective with regard to the 'touristification' of folk performing arts, people can apply the concept of authenticity through the preservation of cultural properties. In Japan, this strategy is commonly done among people in performing art community and it 'not only influences the local conditions within which folk performing arts exist, but also enables the birth of new cultural forms linked to folk performing arts' (1998, p. 35). Such conditions also occur in Indonesia in which artists, organizers, and patrons react to people and environments: the way colleagues think of nature, the system people 
behave in new situation, the method villagers react to others, and the means they use ethics and norms in community. Using new approach and treatment they adopt the basic concepts from the environments and synthesize them into rural norms and values by which people formulate ideas to create new folk performing arts. Doing this, they appropriate ideas and concepts not only to react to old ideas in which traditions should be kept static without change rather they intend to renew perspectives for both formulating proper ideas for recent contexts and constructing basic frameworks for the representation of new performing arts.

Our project followed the above principles, working to transfer the values of a living tradition to a new context, working with local practitioners to re-create and rearticulate rural arts in a way that would be both accessible to tourists on a brief visit and trupe to the essence of the local culture, that is, the meanings it holds and the values it represents for local people. Above all, we were aiming to explore new ways to express the character of the area, through marriage of arts, nature, and the people raised among them.

Although we based the performance on local cultural elements, our aim was not preservation of ancient traditions, or the most accurate or professional reproduction of local artforms. As a community project, the important thing was that local people would be involved in creating, performing and fulfilling supporting roles for the event, and that it would have meaning for people not just because it drew on a local story, but because by repurposing it in this way, it gave a chance to express something unique about the character of the area to visitors.

From the above discussion, we can say that an articulation of traditional art should not aim to achieve a singular vision of authenticity (Theodossopoulos, 2013, p. 397), rather it should be open to a variety of possible manifestations of originality depending on the conditions. In other words, artists have a great deal of freedom in terms of how they articulate authenticity in cultural practices. How these ideas were brought into practice is explored in the following passages.

\section{Presenting authenticity through the performing arts}

Our goal was to create a performance that would present the Parangijo area in a way that was authentic for both the artists involved and for visitors to the area. The elements of the performance were intricately linked to the territory - the rice fields, the forests and the waterfall - and local cultural traditions, all integrated and reinterpreted to create a representation of place built on integrity, respect for the past, and modern perspectives.

What did the local artists want to offer in this performance? People were keen to express something of rural life to audiences. More specifically, they wanted to promote their locality in a way that outsiders could relate to. Solidarity and unity were often raised as important to the villagers, and something they felt would attract the interest of visitors.

One challenge was how to resolve the often conflicting ideas of authenticity. While most members of the public hold 'a nostalgic view of folk performing arts, which [are] identified with concepts such as "tradition", "simplicity", and "archaism"' (Hashimoto, 2003, p. 228), for practitioners, authencity is not a static concept, but a dynamic condition of the constant creation of new meanings. From this perspective, the integrity of a performance depends on its relevance in the present as much as on its roots in the past. 
To resolve this, we took a three-pronged approach: understanding local worldviews and identity (level 1); exploring the manifestations of these through the arts and integrating them into a performance (level 2); 'performing the identity' of the village to an outside audience (level 3).

The first stage for the research team involved becoming acquainted with the concepts that are important to the life of the community, to understand its values and worldview the fundamental elements of a society's 'cultural property' (Hashimoto, 1998, p. 39). From conversations and participation in local ceremonies, it was clear that solidarity and unity were important features of village life, expressed through social gatherings, religious activities, economic activities and artistic creation. This is why the story of Macan Gadhungan made such a perfect choice; villagers felt it symbolized the identity of the village, and would make a captivating narrative on which to build the performance.

The second stage was to integrate local forms of dance and music into a coherent dramatic form that could be presented on stage. Since many aspects, such as the bamboo music, or the reyog-based dance moves, did not develop as elements of a staged drama, this involved adapting and recontextualizing the source material to fit the new context, to represent the dynamics of village life and support the drama of the story. This role was begun by the professional artists involved in the production, but continued to be developed through the workshop/rehearsal process with villagers.

The third level involved presenting the performance. The natural setting was a key element in this, simultaneously drawing the audience into the narrative and reminding them of the story's connection to the real life of the village. By setting the performance within the very landscape it refers to, the environment becomes a kind of protagonist in itself: the drought-ridden garden, the irrigation system, the river, the forest which shelters the tigers and centipedes, become as vital a part of the story as any of the human (or animal) protagonists. Audience members, settling themselves at whim within the performance space - within the story - can experience in the most direct way the land from which it sprung.

The final performance, then, involved marrying the various elements - story, music, choreography and landscape - into a coherent expression of Parangijo. The actors weave their action through the natural landscape, making use of the waterfall, the river, the fields and the forest; the calm bamboo music and the colours of the costumes reflected the character of the environment, and even the chill mountain air heightened the atmosphere of the performance. This carefully integrated presentation itself reflected the values of solidarity, of unity, of living in the midst of nature, that the villagers wished to communicate through the performance.

These three levels of engagement, illustrated in Figure 5 below, can together be described as a process of 'authetication'. Rather than discrete steps, each layer feeds into and emphasizes the other, creating a multi-layered aesthetic whole, an artistic web that can represent an aesthetic expression of local identity, rather than the one-dimensional presentation of 'colourful local traditions' commonly encountered in performances aimed at tourists.

Of course, there is another element of the performance which we must not fail to examine. The very act of integrating these diverse aspects of Ngargoyoso life into a staged performance, in an unconventional setting, unconnected to any traditional celebration, and aimed specifically at visiting tourists, represents a recontextualization of local 


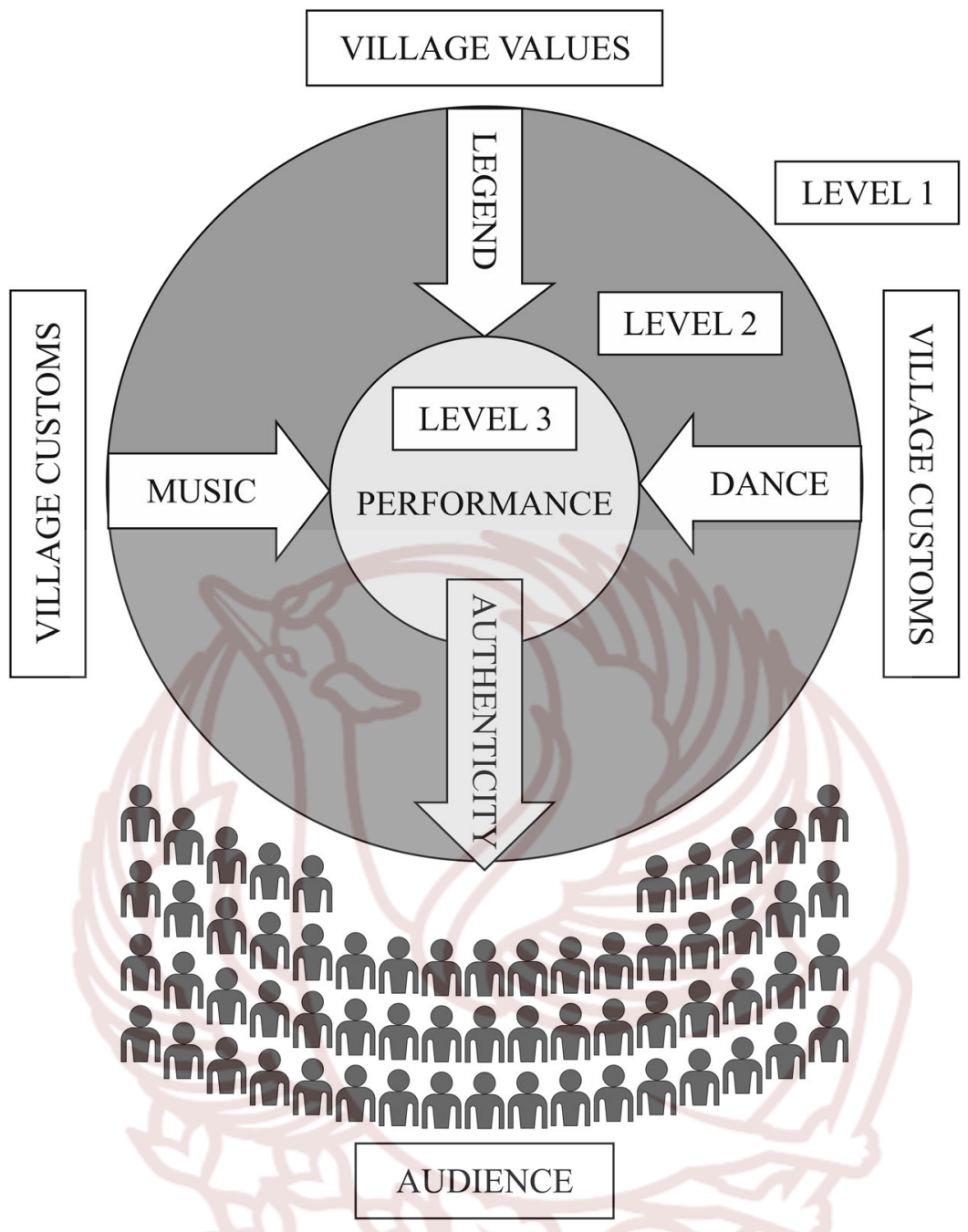

Figure 5. Three-level authentication process for creating the performance.

arts, driven by expectations and aesthetic ideals from outside the village - the expectations of the audience, in other words.

To make this self-expression of identity accessible to vistors, elements of traditional arts - dance, music, legend, nature, and village life - are reinterpreted, modified and adjusted to converse with other elements they don't normally interact with, in order to construct a coherent and cohesive performance. Although each of the elements is, of course, changed by this process, it can be used to create something with new meaning, an artistic articulation not only of village identity, but of basic human values that reverberate beyond the borders of the village, or the region, connecting with our shared human experience.

Facilitating this act of recontextualization or rearticulation constituted the main contribution of the research team, who brought in their knowledge and experience of presenting the arts to modern audiences, as well as expertise in composition, choreography and staging for a large-scale dance drama. 
As society changes, the meanings attached to the artforms which form a part of the cultural life of the society also change. It is the role of artists to explore the possibilities of these new meanings, such that the arts continue to bear significance and serve a function within that community (Luvaas, 2009, p. 264). This process occurs in every performance, as old meanings are revised and metamorphosize into new ones - both within the artistic process and in the audience's interpretation. In creating a performance for tourists, we aimed to accommodate new aspirations and to recontextualize meanings to the contemporary situation, offering a kind of authenticity that is carefully nurtured through a creative artistic process, rather than one which conforms to stereotypes of an idealized, simple rural folk setting.

\section{Epilogue}

The modern world has brought many changes to the way art is both created and experienced. A story told to children, a religious ritual practiced within the community, handicrafts once essential to life, can all be recontextualized to fit the aesthetics and needs of modern society. Indeed, some might argue that it is essential to do so if the skills and knowledge and narratives handed down through generations are not to be lost as their old meanings and relevance evaporates in the wake of technological revolution. By working closely with the communities of Ngargoyoso to understand the rich variety of local traditions - not only performing arts and stories, but the values that they represent - the research team aimed to support rural artists in creating an artwork that grews organically from its physical and human environment, whilst responding to the new needs, desires and aspirations of contemporary audiences.

A crucial question arises: how we market the new performing art considering that this performance was not conventionally proper to the traditional setting and environments? If people in community, students at schools, workers at factories, and chiefs in villages were not familiar with the art and they evaluated the performance as not original, not authentic, and 'strange' artistic expression how can they make sense of it? When re-creating the art we used conventional properties and environments hoping that prospective audiences would appreciate the art as a new approach to elements of the area in new contexts. On the day of the performance, although we did not promote the show extensively, the response was spectacular: the number of audiences were beyond our expectations and their comments were positive. It was because, I believe, the integration and synthesis of local legend, dance, music, craft, and nature could represent new values of the village and environments. Watching the performance attracted people to undertand the values behind the performance: solidarity, cooperative work, peacefullness, good and evil behaviours, and justice. In the future, if it is staged regularly and coupled with extensive promotion - through radios, newspapers, television, and social media - it will reach wider audiences. Letting stake holders - tourist agencies, school teachers, farm workers, village officers, community leaders, and others - get involved more intensively in performances will interest them to extract the deep meanings of the art in contemporary contexts, the dream of our team when proposed the performance to the village officers.

\section{Note}

1. http://www.indonesia-tourism.com/central-java/sukuh-temple.html 


\section{Disclosure statement}

The author of this publication received research grant from Ministry of Research, Technology and Higher Education (Indonesia) contract number 4923/16.2/PL/2009 dated 9 July 2009 and he does not have any conflict of interest with that institution.

\section{Funding}

This research was funded by the Directorate General of Higher Education (DGHE), Jakarta (Indonesia) under Penelitian Strategis Nasional scheme, contract number 4923/16.2/PL/2009, 9 July 2009.

\section{Notes on contributor}

Santosa Soewarlan is a lecturer at Indonesia Institute of the Arts (ISI) Surakarta. Indonesia. He has conducted research in various field such as: music, communication, identity, and meanings.

\section{References}

Albert, H.C., \& Helen, D.H. (2010). Maintaining authenticity and integrity at cultural world heritage sites. The Geographical Review, 100(1), 56-73.

Barker, J. (1999). Surveillance and territoriality in Bandung. In V. L. Rafael (Ed.), Figures of criminality in Indonesia, the Philippines, and Vietnam (pp. 95-127). Ithaca: Southeast Asian Program Publication, Cornell University.

Connell, S. (2014). The poetics and politics of legend: Geoffrey Keating's Foras Feasa ar Eirinn and the invention of Irish history. The Journal for Early Modern Cultural Studies, 14(3), 83-106.

Davies, D. (2004). Art as performance. Malden: Blackwell Publishing Ltd.

della Dora, V., Lorimer, H., \& Daniels, S. (2011). Denis Cosgrove and Stephen Daniels (eds). (1988). The iconography of landscape: Essays on the symbolic representation, design and Use of past environments. Progress in Human Geography, 35(2), 264-270.

Freytag, G. (1876). Die Technik des Dramas. Leipzig: Berlag von G. Birgel.

Geertz, C. (1960). The Religion of Java. Chicago: University of Chicago Press.

Hashimoto, H. (1998). Re-Creating and re-imagining folk performing arts in contemporary Japan. Journal of Folklore Research, 35(1), 35-46.

Hashimoto, H. (2003). Between preservation and tourism: Folk performing arts in contemporary Japan. Asian Folklore Studies, 62(2), 225-236.

Human, B. (2010). Tourism and place: towards an alliance of policies. Musical Engineer, 173(3), 131138.

Luvaas, B. (2009). Dislocating sounds: The deterritorialization of Indonesian indie pop. Cultural Anthropology, 24(2), 246-279.

Mbaiwa, J.E. (2004). The socio-cultural impact of tourism development in the Okavango delta, Botswana. Journal of Tourism and Cultural Change, 2(3), 163-185.

McDonald, M., Antunez, G., \& Gottemoeller, M. (2006). Using the arts and literature in health education. International Quarterly of Community Health Education, 27(3), 265-278.

Rogerson, C.M., \& Rogerson, J.M. (2014). Urban tourism destinations in South Africa: Divergent trajectories 2001-2012. Urbani Izziz, 25, S189-S203.

Schippers, H. (2006). Tradition, authenticity and context: The case for a dynamic approach. British Journal of Music Education, 23(3), 333-349.

Smith, A. (2009). Using major events to promote peripheral urban areas: Deptford and the 2007 tour de France. In J. Ali-Knight, M. Robertson, A. Fyall, \& A. Ladkin (Eds.), International perspectives of festivals and events: Paradigms of analysis (pp. 3-20). London: Academic Press.

Tan, Z., \& Yang, J. (2014). New views on tourism resources in changing Era. Applied Mechanics and Materials, 543-547, 4370-4373. 
Theodossopoulos, D. (2013). Embera indigenous tourism and the trap of authenticity: Beyond inauthenticity and invention. Anthropological Quarterly, 86(2), 397-425.

Yamashita, S. (1999). Bali: Cultural tourism and touristic culture. Indonesia, 67, 177-182.

Zhang, J. (2013). The issues facing the sustainable development of rural tourism and the path selection. Asian Agricultural Research, 5(9), 5-7.

Zie, T. (2015). Overview of rural tourism in China. Asian Agricultural Research, 7(1), 13-17. 